\title{
The effects of elevated subcutaneous fat stores on fatty acid composition and gene expression of proinflammatory markers in periparturient dairy cows
}

\author{
Cynthia M. Scholte, Pedram Rezamand, ${ }^{1}$ Chia-Yu Tsai, Zahra M. Amiri, Kirk C. Ramsey, and Mark A. McGuire \\ Department of Animal and Veterinary Science, University of Idaho, Moscow 83844
}

\begin{abstract}
During the periparturient period, elevated circulating nonesterified fatty acids (NEFA) from excessive lipid mobilization affect not only the circulating fatty acid (FA) composition, but also that of the peripheral blood mononuclear cells (PBMC) and polymorphonuclear leukocytes (PMNL). However, the changes to specific lipid fractions remain unknown. We hypothesized that elevated lipid mobilization will alter FA profiles and gene expression of selected proinflammatory mediators in PBMC and PMNL. Starting $-28 \mathrm{~d}$ relative to expected calving $(\mathrm{d} 0)$, treatment cows $(\mathrm{n}=18)$ received a dry cow ration plus an additional $10 \mathrm{~kg}$ of corn/head per day, while the control cows $(n=16)$ received the dry cow ration (no additional corn) supplemented with $400 \mathrm{mg}$ of monensin/head per day to minimize lipid mobilization. Postpartum, treatment cows were feed deprived for $8 \mathrm{~h}$ on $\mathrm{d}+3$. For FA analysis, serum was collected on $\mathrm{d}-28$ and -7 relative to expected parturition and $\mathrm{d}+1,+3,+6,+15$, and +21 postpartum, in addition to milk samples. Immune cells, PBMC and PMNL, were isolated on $\mathrm{d}-28,+3,+12$, and +21 for FA analysis and gene expression analysis by reversetranscription PCR. Serum, PBMC, and PMNL lipids were fractionated into NEFA and phospholipids (PL). The FA composition of milk, serum, PBMC, and PMNL was analyzed by gas chromatography. Data were analyzed as repeated measures ANOVA using mixed model procedures in SAS (9.3) with significance declared at $P$ $\leq 0.05$. Several FA varied by treatment and across time and parity. Within the serum PL fraction, FA associated with altered immune function, C18:3n-6, C20:4, $\mathrm{C} 20: 5$, total $\mathrm{n}-3$, and the ratio of $\mathrm{n}-6$ to $\mathrm{n}-3$ varied significantly by a treatment $\times$ parity $\times$ time interaction. Overall, FA composition of NEFA and PL fractions from PBMC and PMNL did not significantly reflect FA of serum. Gene expression for $I L-1 \beta$ in PBMC was greater for control, whereas $I C A M, I L-1 \beta, I L-6$, and
\end{abstract}

Received June 13, 2016.

Accepted October 27, 2016.

${ }^{1}$ Corresponding author: rezamand@uidaho.edu
$T N F-\alpha$ were greater in primiparous than multiparous cows, without a detectable treatment effect. Whereas gene expression of $C A S P, I L-8 R$, and $S E L L$ in PMNL changed over time, no treatment effect was detected. In summary, high-energy prepartal diets altered FA profile in serum, milk, PBMC, and PMNL lipids; however, gene expression of selected proinflammatory mediators was not significantly affected.

Key words: fatty acid, peripheral mononuclear cell, polymorphonucleocyte, gene expression

\section{INTRODUCTION}

One of the primary challenges faced by cows during the periparturient period is the substantial increase in nutrient requirements when supply is inadequate from insufficient DMI. To compensate for this negative nutrient balance, cows mobilize lipid stores (Goff, 2006).

Lipids are transported and found in various fractions in blood and tissue including neutral lipids, nonesterified fatty acids (NEFA), and phospholipids (PL). Neutral lipids, such as triglycerides and cholesterol esters, are the most abundant fraction of lipids. During the transition period, high-producing dairy cows experience lipid mobilization and elevated circulating concentrations of NEFA. This can overwhelm and disrupt liver function, leading to fatty liver disorder, ketosis, and other metabolic disorders (Rukkwamsuk et al., 1999).

Altering the fatty acid (FA) profile of PL may alter eicosanoid metabolism and synthesis of inflammatory mediators. For example, supplementation of n-3 FA in the diet increases n-3 concentrations in the PL fraction and alters the eicosanoid metabolism to produce less potent proinflammatory mediators and more anti-inflammatory mediators and to reduce cytokine production in immune cells, such as peripheral blood mononuclear cells (PBMC) and PMNL (Calder, 2005). In contrast, elevated NEFA concentrations from excessive lipid mobilization are shown to decrease immune cell function and alter population distributions (Lacetera et al., 2004; Scalia et al., 2006), ultimately affecting overall immune responses within the cow.

The objective of this study was to determine the effects of prepartum dietary manipulation to increase 
subcutaneous lipid stores and elevate periparturient lipid mobilization on serum, PBMC and PMNL FA profile in NEFA and PL fractions as well as PBMC and PMNL gene expression of proinflammatory cytokines and adhesion molecules.

\section{MATERIALS AND METHODS}

A total of 34 (14 primiparous and 20 multiparous) healthy Holstein dairy cows were included in the experiment from $d-28$ through $d+21$, relative to expected parturition ( $\mathrm{d} 0$ ). Cows were blocked by parity and assigned to 1 of 2 groups administered prepartum: control and treatment. Control animals received the basal dry cow ration with an additional $400 \mathrm{mg}$ of monensin/ head per day (in $0.23 \mathrm{~kg}$ of corn) to minimize lipid mobilization. Treatment animals received the basal dry cow ration with an additional $10 \mathrm{~kg}$ of dry, cracked corn/head per day and were then fasted for $8 \mathrm{~h}$ on $\mathrm{d}+3$ postpartum to promote lipid mobilization. All multiparous cows received $0.23 \mathrm{~kg} /$ head of SoyChlor (West Central, Ralston, IA) starting d -14 through parturition to help maintain desired dietary cation-anion balance and reduce risk of milk fever.

Cows were housed in open pens prepartum and tiestalls postpartum. Free choice water was available and cows were fed ad libitum twice daily to ensure 5 to $10 \%$ refusals. Cows were fed by pen prepartum and individually postpartum, and intake was recorded daily. Prepartum, cows were fed a total mixed ration $(46.4 \%$ $\mathrm{DM})$ with the following ingredients: triticale silage (44.3\%), 50:50 oat and pea silage (14.8\%), alfalfa hay $(12.9 \%)$, grass hay $(10.0 \%)$, dry rolled barley $(9.0 \%)$, liquid mineral/vitamin premix $(5.0 \%$; Performix Nutrition Systems, Caldwell, ID), cracked corn (4.0\%), and salt $(0.2 \%)$. The basal prepartum ration contained (on a DM basis) $12.1 \% \mathrm{CP}, 34.4 \% \mathrm{ADF}, 51.6 \% \mathrm{NDF}, 2.8 \%$ ether extract, $0.7 \% \mathrm{Ca}, 0.3 \% \mathrm{P}, 2.5 \% \mathrm{~K}, 0.2 \% \mathrm{Mg}$, and $1.39 \mathrm{Mcal}$ of predicted $\mathrm{NE}_{\mathrm{L}} / \mathrm{kg}$. Postpartum, cows were fed a total mixed ration $(62.3 \% \mathrm{DM})$ consisting of triticale silage $(30.0 \%)$, canola meal $(17.1 \%)$, dry rolled barley (16.4\%), dry distillers grains with soluble $(9.0 \%)$, cracked corn $(7.2 \%)$, alfalfa hay $(6.4 \%)$, grass hay (6.4\%), liquid mineral/vitamin premix (4.5\%), calcium soaps of FA (2.3\%; EnerGII; Virtus Nutrition, Corcoran, CA), sodium bicarbonate $(0.5 \%)$, and salt $(0.2 \%)$. The postpartum ration contained (on a DM basis) $17.6 \% \mathrm{CP}, 24.5 \% \mathrm{ADF}, 38.4 \% \mathrm{NDF}, 5.6 \%$ ether extract, $0.9 \% \mathrm{Ca}, 0.5 \% \mathrm{P}, 1.8 \% \mathrm{~K}, 0.3 \% \mathrm{Mg}$, and 1.64 Mcal of predicted $\mathrm{NE}_{\mathrm{L}} / \mathrm{kg}$.

Cows were milked 3 times daily at 0600, 1400, and $2200 \mathrm{~h}$ in a double-4 herringbone parlor with milk yields recorded daily. Energy corrected milk was calculated using the following equation: $0.327 \times$ milk yield $(\mathrm{kg})$
$+12.95 \times$ fat yield $(\mathrm{kg})+7.65 \times$ protein yield $(\mathrm{kg})$. Cows were assessed for BCS (Wildman et al., 1982) and BW on $\mathrm{d}-28$ and -7 relative to predicted parturition and then $+3,+12$, and $+21 \mathrm{~d}$ thereafter by 2 trained observers, and averaged values were used. Results for BCS are not reported here because of errors made during measurement. All procedures involving animals were approved by the University of Idaho Animal Care and Use Committee (Protocol 2011-24).

\section{Sample Collection}

Blood samples were obtained on $\mathrm{d}-28$ and -7 relative to expected calving and $\mathrm{d}+1,+3,+6,+15$, and +21 . Approximately 7 to $10 \mathrm{~mL}$ of blood was collected via coccygeal venipuncture into serum BD Vacutainers (Becton, Dickinson and Company, Franklin Lakes, NJ). Blood was allowed to coagulate for $24 \mathrm{~h}$ before serum was obtained after centrifugation $\left(1,500 \times g\right.$ at $4^{\circ} \mathrm{C}$ for $15 \mathrm{~min})$.

Additional blood samples were obtained on d -28 , $+3,+12$, and +21 , relative to calving for PBMC and PMNL isolation. Approximately $50 \mathrm{~mL}$ of blood was collected via jugular venipuncture and $100 \mu \mathrm{L}$ of 180 USP units of sodium heparin (Sigma Aldrich, St. Louis, MO) were added. After centrifugation $(740 \times$ $g$ at $10^{\circ} \mathrm{C}$ for $10 \mathrm{~min}$ ), plasma was removed and red blood cells were lysed with sterile water for $20 \mathrm{~s}$ before adding $2.5 \mathrm{~mL}$ of sterile $10 \% \mathrm{NaCl}$ solution to stop lysis. The PBMC and PMNL were isolated by gradient centrifugation using Histopaque 1077 and 1119 (Sigma Aldrich). Isolated PBMC and PMNL were washed in Hanks' balanced salt solution (HBSS; Sigma Aldrich) and then resuspended in $5 \mathrm{~mL}$ of HBSS. Cell suspensions were aliquoted into 2 tubes and stored at $-80^{\circ} \mathrm{C}$ for gene expression and FA analysis.

Milk was collected on $\mathrm{d}+1,+3,+6,+15$, and +21 postpartum at all 3 milkings on the sample day and pooled in proportion to the yield at each milking. Fifteen milliliters of milk was stored at $-20^{\circ} \mathrm{C}$ before being analyzed for FA; milk urea nitrogen (Minnesota DHIA, Zumbrota, MN); fat, true protein, and lactose via infrared spectroscopy; solids-not-fat; and SCC by Fossomatic analysis (Washington DHIA, Burlington, WA).

\section{Lipid Analysis}

Lipids were extracted from the feed, serum, milk, PBMC, and PMNL using chloroform:methanol (2:1) as previously described by Clark et al. (1982). Serum, PBMC, and PMNL lipids were fractionated through silica-based, solid bonded phase Sep-Pak aminopropyl (NH2) cartridges (Waters Corporation, Milford, MA) 
to yield 3 fractions: neutral lipid (NL), NEFA, and PL. The NL fraction was eluted via chloroform:2-propanol $(2: 1)$, the NEFA fraction via $2 \%$ acetic acid in ethyl ether, and the PL fraction via methanol (Kaluzny et al., 1985). The NEFA and PL fractions of serum, PBMC, and PMNL along with extracted milk lipids were methylated using $0.5 \mathrm{M}$ sodium methoxide in a 2-step procedure (Kramer et al., 1997). Fatty acid methyl esters were analyzed with an Agilent 7890A gas chromatograph equipped with an auto sampler, flame ionization detector, and an Agilent J\&W HP-88 column (100 m $\times$ $0.250 \mathrm{~mm} \times 0.20 \mu \mathrm{m}$ film; Agilent Technologies, Santa Clara, CA) in a modified 45-min method as described by Scholte et al. (2014). Peaks were identified using a Supelco 37 Component FAME Mix (Sigma-Aldrich). Within each lipid sample, all identified peaks were used to calculate total FAME. Individual FA (g/100 g of FAME) were calculated as individual FA divided by total FAME.

\section{Gene Expression Analysis}

Total RNA was collected from PBMC and PMNL using the NucloSpin RNA kit (Machery-Nagel, Duren, Germany) according to the manufacturer's instructions. A NanoDrop ND-1000 (NanoDrop Technologies, Rockland, DE) spectrophotometer was used to determine RNA concentration. One hundred nanograms of RNA was used for synthesis of single-stranded cDNA using the Applied Biosystems High-Capacity cDNA Reverse Transcription kit (Applied Biosystems, Foster City, CA). Single-stranded cDNA was then used for gene expression analysis with a 7500 Fast Real-Time System (Applied Biosystems), and PCR of 20- $\mu \mathrm{L}$ samples was done in duplicate using Taqman Universal PCR Master Mix (Applied Biosystems) and Custom Taqman Gene Expression assays (Applied Biosystems). Expression of IL-1 $\beta$ ( $I L-1 \beta$; accession number NM_174903.1), IL-6 (IL-6; NM_174923.2), intercellular adhesion molecule 1 (ICAM; NM_174348.2), and tumor necrosis factor- $\alpha$ (TNF- $\alpha$; NM_001101152.2) was measured in PBMC. Interleukin-8 receptor ( $I L$ 8R; DQ389113), L-selectin (SELL; NM_174182.1), and caspase-1 (CASP; XM_002692921) expression was measured in PMNL relative to endogenous controls, glyceraldehyde 3-phophate dehydrogenase (GAPDH; NM_001034034.2) and ribosomal protein S9 (RPS9; NM_001101152.2). Primer/probe set for $I L-8 R$ (forward primer: ATGCGGGTCATCTTTGCTG; reverse primer: ATGAGGGTGTCCGCGATC; probe: CTCGTCTTCCTGCTCTGCTGGCT) was designed using Primer Express software v. 1.5 (Applied Biosystems). Caspase-1 was designed by Custom Plus TaqMan RNA
Assay (Applied Biosystems). All other gene primer/ probe sets were developed by Applied Biosystems.

\section{Data Analysis}

Response variables were analyzed as repeated measures using the MIXED model procedure (Version 9.3, SAS Institute Inc., Cary, NC). Sources of variation in the model included effects of treatment, time, and parity as well as 2- and 3-way interactions among the main effects. Cow nested within treatment $\times$ parity was designated as a random effect in the model. Significance was declared at $P \leq 0.05$. Data are presented as least squares means $(\mathbf{L S M}) \pm$ standard errors of the mean (SEM). Gene expression data were analyzed using Ct values normalized to the average of the endogenous control genes GAPDH and RPS9. Gene expression data over time are expressed as fold change $\left(2^{-\Delta \Delta \mathrm{Ct}}\right)$ relative to $\mathrm{d}-28$.

\section{RESULTS AND DISCUSSION}

\section{Fatty Acid Analysis}

In the current study, serum lipids were fractionated into NEFA and PL and several FA differed from the high-energy (prepartum) ration. Although NEFA typically constitute less than $1 \%$ of the total circulating lipid fractions (Quehenberger et al., 2010), total concentration increases slightly over the prepartum period, peaks shortly after parturition, and decreases through postpartum (Scholte et al., 2014). Total serum NEFA concentrations were not determined in the present study; however, it is possible to speculate that a similar pattern would have occurred based on previous studies. In the NEFA fraction, sum of $\mathrm{C} 18: 1$ cis $(P<0.01)$ and all cis-9,12-C18:2 (C18:2 cis; $P<0.01)$ differed, and C18:0 $(P<0.10)$ tended to differ by treatment across parity and the periparturient period (i.e., time; Table 1). Given the high degree of lipid mobilization in the form of NEFA to compensate for severe negative energy balance in the periparturient period (Goff, 2006) and the primary FA of subcutaneous adipose tissue being C16:0, C18:0, and C18:1 (Douglas et al., 2007), it is not surprising that these FA changed over time. The control group had greater concentrations of C18:3n-3 (1.3 vs. $1.0 \pm 0.1 \mathrm{~g} / 100 \mathrm{~g}$ of FAME; $P=$ 0.04) in serum NEFA than the treatment group, with the greatest concentration just before parturition $(P=$ 0.02; Figure 1). A proportion of the C18:3n-3 from the serum NEFA fraction could have potentially been used by the mammary gland for milk fat synthesis; however, their true origin (diet or mobilized from lipid stores) 
Table 1. Least squares means of FAME (g/100 g) of the nonesterified fatty acid fraction of serum obtained from dairy cows [14 multiparous (M) and 20 primiparous $(\mathrm{P})$ ] that received either the treatment of $10 \mathrm{~kg}$ of corn/head per day prepartum and were fasted for $8 \mathrm{~h}$ on $\mathrm{d} 3$ postpartum (TRT) or control of $400 \mathrm{mg}$ of monensin/head per day prepartum (CON) throughout the periparturient period

\begin{tabular}{|c|c|c|c|c|c|c|c|c|}
\hline Fatty acid, g/100 g & \multicolumn{2}{|c|}{ TRT } & \multicolumn{2}{|c|}{$\mathrm{CON}$} & $\mathrm{SEM}^{1}$ & \multicolumn{3}{|c|}{$P$-value } \\
\hline C14:0 & 3.6 & 2.8 & 3.1 & 3.4 & 0.4 & 0.76 & 0.46 & 0.18 \\
\hline $\mathrm{C} 15: 0$ & 0.74 & 0.74 & 0.76 & 0.98 & 0.11 & 0.19 & 0.24 & 0.24 \\
\hline C15:1 & 0.32 & 0.46 & 0.54 & 0.59 & 0.18 & 0.22 & 0.27 & 0.57 \\
\hline C16:0 & 28.0 & 27.4 & 27.9 & 27.6 & 0.7 & 0.89 & 0.70 & 0.04 \\
\hline $\mathrm{C} 17: 1$ & 0.26 & 0.56 & 0.34 & 0.37 & 0.14 & 0.59 & 0.70 & 0.95 \\
\hline C18:0 & 23.0 & 24.8 & 24.4 & 25.0 & 1.0 & 0.41 & 0.22 & 0.10 \\
\hline C18:1 trans -9 & 1.42 & 2.1 & 1.6 & 1.9 & 0.3 & 0.97 & 0.54 & 0.24 \\
\hline C18:1 cis-9 & 22.7 & 21.8 & 21.9 & 19.0 & 1.3 & 0.13 & 0.41 & $<0.01$ \\
\hline $\mathrm{C} 18: 2$ all trans- 9,12 & 0.07 & 0.08 & 0.08 & 0.08 & 0.02 & 0.81 & 0.26 & 0.07 \\
\hline C18:2 all cis- 9,12 & 7.9 & 7.4 & 7.6 & 6.9 & 0.6 & 0.42 & 0.30 & 0.01 \\
\hline C18:3n-6 & 0.06 & 0.08 & 0.07 & 0.08 & 0.02 & 0.86 & 0.36 & 0.29 \\
\hline $\mathrm{C} 22: 0$ & 0.36 & 0.20 & 0.26 & 0.33 & 0.08 & 0.74 & 0.13 & 0.14 \\
\hline C20:3n-6 & 0.70 & 0.86 & 0.64 & 0.82 & 0.10 & 0.63 & 0.95 & 0.59 \\
\hline C20:3n-3 & 0.18 & 0.19 & 0.26 & 0.30 & 0.09 & 0.19 & 0.52 & $<0.01$ \\
\hline $\mathrm{C} 22: 1$ & 0.31 & 0.35 & 0.27 & 0.22 & 0.08 & 0.19 & 0.32 & 0.17 \\
\hline C20:4 & 1.26 & 0.99 & 0.83 & 0.89 & 0.16 & 0.06 & 0.25 & 0.01 \\
\hline $\mathrm{C} 23: 0$ & 0.30 & 0.27 & 0.26 & 0.34 & 0.09 & 0.84 & 0.39 & 0.74 \\
\hline $\mathrm{C} 22: 2$ & 0.06 & 0.07 & 0.06 & 0.17 & 0.07 & 0.26 & 0.72 & 0.23 \\
\hline C20:5 & 0.33 & 0.32 & 0.26 & 0.38 & 0.09 & 0.92 & 0.62 & 0.48 \\
\hline C24:0 & 0.20 & 0.19 & 0.20 & 0.28 & 0.07 & 0.47 & 0.10 & 0.24 \\
\hline $\mathrm{C} 24: 1$ & 0.08 & 0.05 & 0.04 & 0.14 & 0.07 & 0.66 & 0.60 & 0.31 \\
\hline $\mathrm{C} 22: 6$ & 0.04 & 0.18 & 0.01 & 0.27 & 0.19 & 0.88 & 0.47 & 0.73 \\
\hline$\Sigma \mathrm{SFA}$ & 58.1 & 58.6 & 59.2 & 60.7 & 1.4 & 0.19 & 0.93 & 0.19 \\
\hline$\Sigma$ UFA & 41.9 & 41.4 & 40.8 & 39.3 & 1.4 & 0.19 & 0.93 & 0.19 \\
\hline$\Sigma$ MUFA & 30.1 & 30.2 & 29.9 & 27.7 & 1.7 & 0.37 & 0.64 & $<0.01$ \\
\hline
\end{tabular}

${ }^{1}$ Largest SEM reported.

${ }^{2} \mathrm{n}-6$ included C18:2 all trans-9,12, C18:2 all cis-9,12, C18:3n-6, C20:2, C20:3n-6, C20:4, and C22:2.

${ }^{3} \mathrm{n}-3$ included C18:3n-3, C20:3n-3, C20:5, and C22:6.

remains unknown because FA were not labeled in the current study. Eicosanoid precursor, C20:4, tended to have greater concentrations in treatment animals $(0.86$ vs. $1.12 \pm 0.10 \mathrm{~g} / 100 \mathrm{~g}$ of FAME, $P=0.06)$, potentially increasing available substrate for increased synthesis of eicosanoid and proinflammatory mediators. Several other long-chain PUFA, such as C20:5 and C22:6, had no detectable differences between treatments, possibly because of high variation between samples and relatively low concentrations present in periparturient cows' serum (Contreras et al., 2010).

Within bovine plasma, PL concentrations are approximately $25 \%$ of the total serum lipid content (Christie, 1981). During the periparturient period, PL concentrations remain constant through the prepartum period and steadily increase with progression of early lactation postpartum (Imhasly et al., 2015). Changes in circulating PL concentration coincide with changes in FA. Several FA associated with eicosanoid production in serum PL varied by treatment across parity and time, as shown in Figure 2 and Table 2. Concentrations of $\mathrm{C} 20: 4$ differed $(P<0.01)$, with multiparous cows having greater prepartum concentrations than primiparous cows. After parturition, concentrations were similar between treatment and parity groups. The n-3 FA C20:5 had concentrations greater in control animals prepartum and primiparous cows postpartum $(P=0.04)$. Contreras et al. (2010) reported values al- 
most half the concentrations of C20:4, yet similar C20:5 concentrations were observed in this study in plasma PL. Greater C20:4 and decreased C20:5 concentrations in multiparous animals as compared with primiparous animals suggests the possibility of a proinflammatory state in multiparous animals because of increased available C20:4 substrate for synthesis of proinflammatory mediators and reduced inhibition of eicosanoid metabolism by C20:5. Ratio of n-6 to n-3 was very high for this fraction, primarily because of low total n-3 and high C18:2 cis concentrations in the serum PL profile. The ratio was greater for treatment animals in the prepartum period and for multiparous cows in the postpartum period. Similar to the serum NEFA fraction, concentrations of $\mathrm{C} 18: 3 \mathrm{n}-3$ varied by treatment $\times$ time $(P<$ $0.01)$ with greater concentrations observed in the control group prepartum, but concentrations postpartum did not differ.

In the present study, few FA in the NEFA fraction of PBMC had significant changes in concentration be-
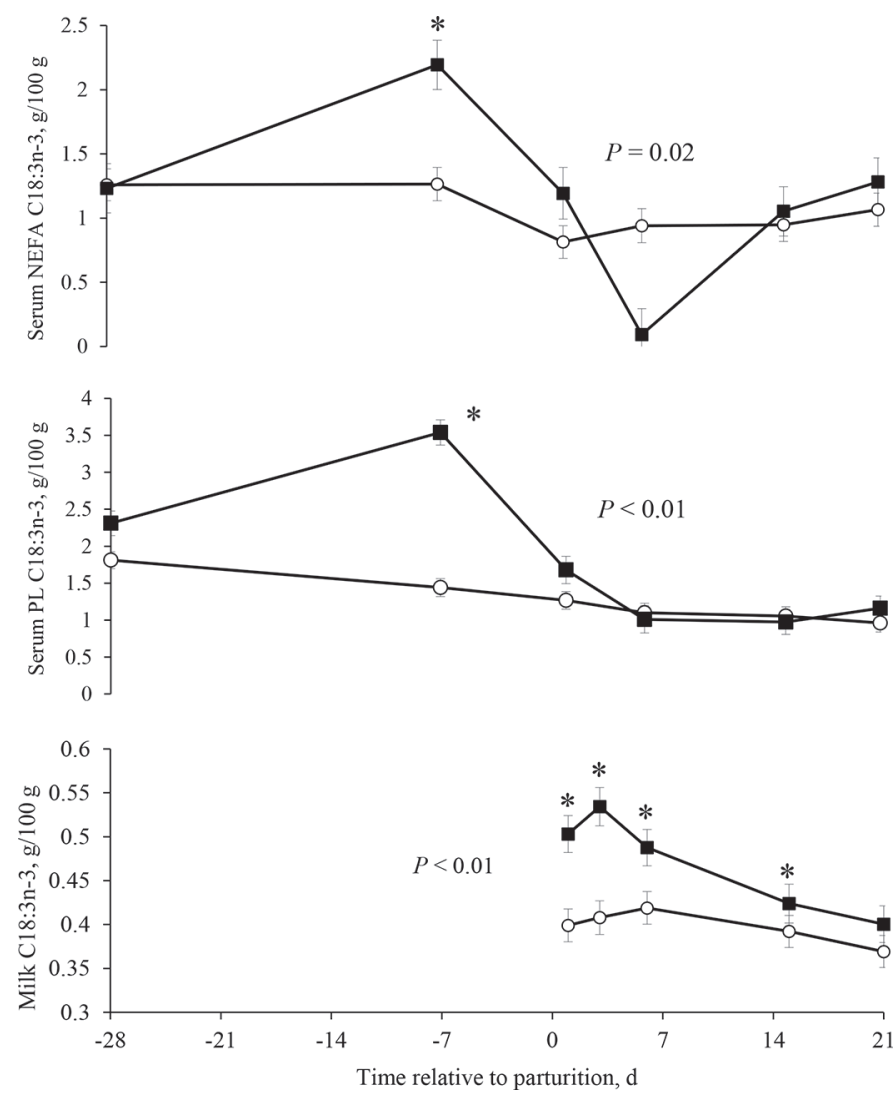

Figure 1. Least squares means $( \pm \mathrm{SE})$ of C18:3n-3 (g/100 g) of the nonesterified fatty acid (NEFA) and phospholipids (PL) fractions of serum and milk lipids from periparturient dairy cows (14 multiparous and 20 primiparous) that received either the treatment (open circle; O) of $10 \mathrm{~kg}$ of corn/head per day prepartum and were fasted for $8 \mathrm{~h}$ on d 3 postpartum or control (closed square; $\mathbf{D}$ ) of $400 \mathrm{mg}$ of monensin/ head per day prepartum. ${ }^{*} P<0.05$.
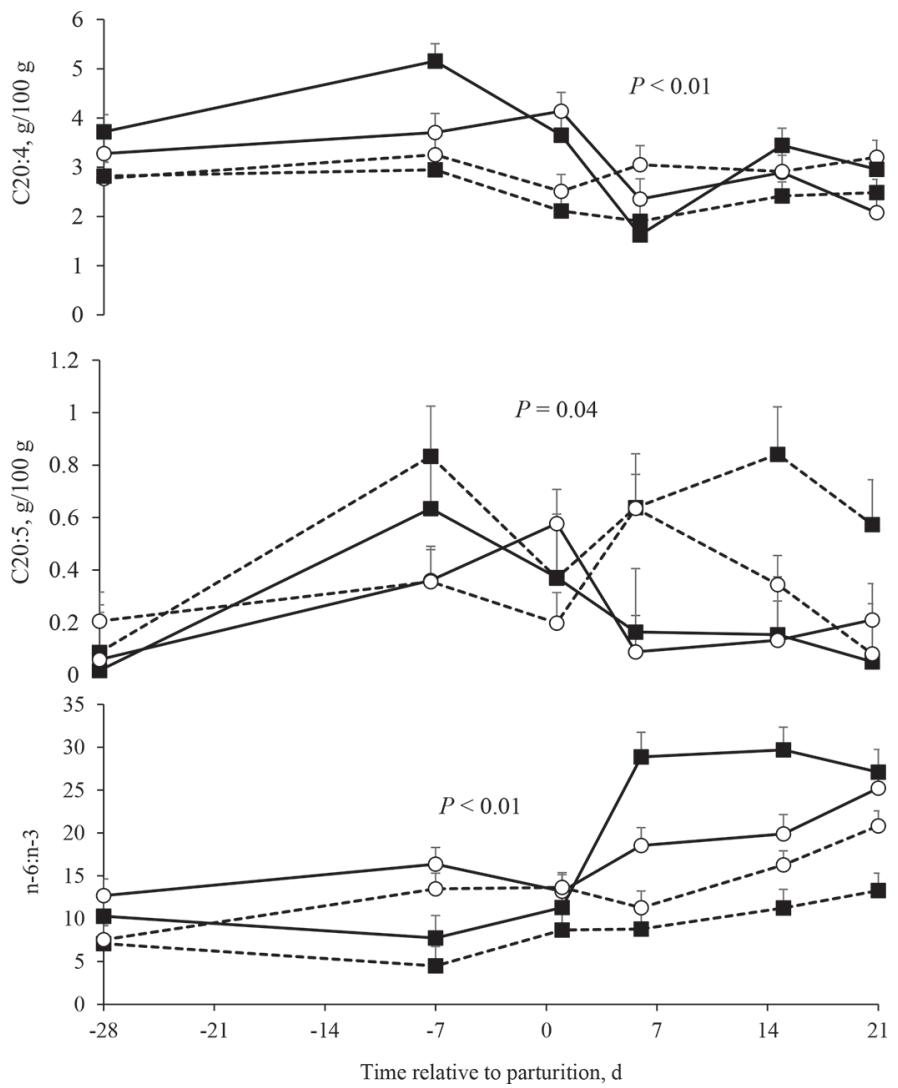

Figure 2. Least squares means ( \pm SE) of C20:4 (g/100 g), C20:5 $(\mathrm{g} / 100 \mathrm{~g})$, and $\mathrm{n}-6: \mathrm{n}-3$ profile of the phospholipids fraction of serum lipid samples obtained from periparturient dairy cows 14 multiparous (solid line) and 20 primiparous (dashed line)] that received either the treatment (open circle; $\mathrm{O}$ ) of $10 \mathrm{~kg}$ of corn/head per day prepartum and were fasted for $8 \mathrm{~h}$ on d 3 postpartum or control (closed square; 口) of $400 \mathrm{mg}$ of monensin/head per day prepartum.

cause of treatment (Table 3). As observed in the serum NEFA profile, concentrations of C20:4 in the NEFA fraction of PBMC were greater in treatment animals compared with control animals (1.29 vs. $0.52 \pm 0.27$ $\mathrm{g} / 100 \mathrm{~g}$ of FAME, $P=0.02)$. Concentrations of C20:4 also varied by treatment across parity and time (Figure $3 ; P=0.02$ ). Primiparous treatment animals had a greater C20:4 prepartum concentration that dropped to concentrations similar to those observed in primiparous control animals. Multiparous animals had greater C20:4 concentrations after parturition before returning to similar concentrations of the primiparous animals at d 21 postpartum. Although no significant difference was detected for sum of n-3 and sum of n- 6 (Table 3 ), the ratio of n- 6 to n-3 varied slightly by treatment across parity and time (Figure $3 ; P=0.05$ ). Concentrations peaked after parturition in primiparous animals as compared with multiparous animals around d 12 postpartum and continued increasing rapidly in treatment animals at 21 DIM. Predominant FA found in 
Table 2. Least squares means of FAME (g/100 g) of the phospholipids fraction of serum obtained from dairy cows [14 multiparous (M) and 20 primiparous $(\mathrm{P})]$ that received either the treatment of $10 \mathrm{~kg}$ of corn/head per day prepartum and were fasted for $8 \mathrm{~h}$ on $\mathrm{d} 3$ postpartum (TRT) or control of $400 \mathrm{mg}$ of monensin/head per day prepartum (CON) throughout the periparturient period

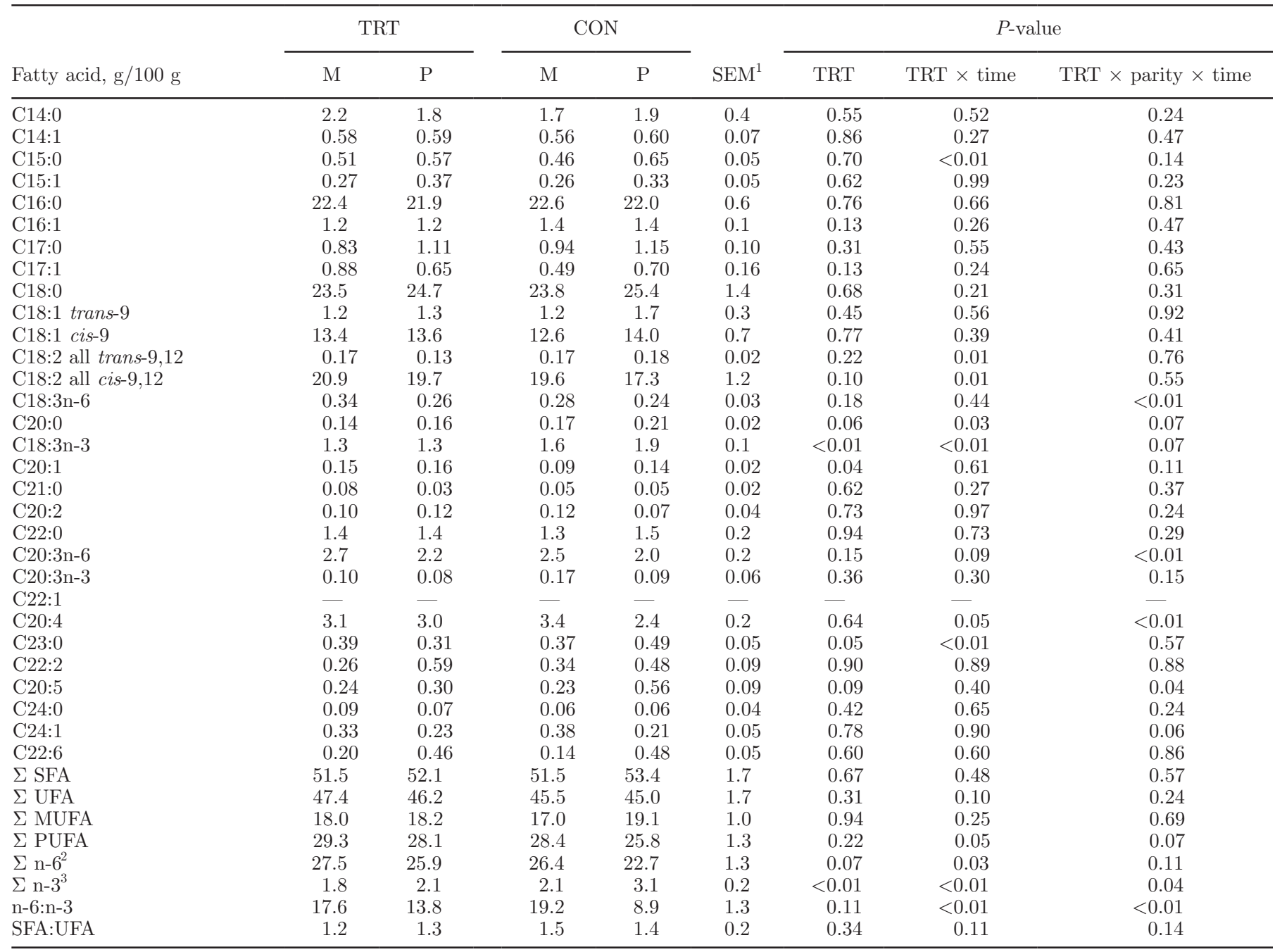

${ }^{1}$ Largest SEM reported.

${ }^{2} \mathrm{n}-6$ included C18:2 all trans-9,12, C18:2 all cis-9,12, C18:3n-6, C20:2, C20:3n-6, C20:4, and C22:2.

${ }^{3} \mathrm{n}-3$ included C18:3n-3, C20:3n-3, C20:5, and C22:6.

the NEFA fraction of PBMC were C16:0 $(27.8 \mathrm{~g} / 100$ g FAME), C18:0 (26.6 g/100 g FAME), and C18:1 cis $(8.0 \mathrm{~g} / 100 \mathrm{~g}$ FAME), similar to the FA profile found in the serum NEFA fraction.

The FA profile of the PL fraction of PBMC has many effects on cellular function. Alteration to the FA composition can result in alterations to membrane properties, inter- and intra-cellular signaling, and lipid mediator synthesis (Calder, 2008). The current experiment had few FA concentrations change in FA profile of the PL fraction of PBMC because of treatment (Table 4). In contrast to PBMC NEFA C20:4 concentrations, the PL fraction had a greater concentration of C20:4 in the control group than in the treatment group (10.1 vs. 8.2 $\pm 0.6 \mathrm{~g} / 100 \mathrm{~g}$ FAME, $P=0.02)$. As C20:4 functions as a substrate for eicosanoid synthesis in human immune cells (Calder, 2005), it is suggested that PBMC obtained from dairy cows fed a typical prepartum diet have the potential to produce more proinflammatory mediators than cows fed a high-energy prepartum diet. Increased synthesis of proinflammatory mediators is essential for immune cells to respond to pathogen challenges; however, excess production can result in a chronic inflammatory state (Calder, 2008). Concentrations of C18:3n-3, a potential precursor for $\mathrm{C} 20: 5$ and $\mathrm{C} 22: 6$ syntheses, were greater in treatment animals than control animals ( 1.07 vs. $0.63 \pm 0.20 \mathrm{~g} / 100 \mathrm{~g}$ FAME, $P=$ $0.04)$. No significant difference was detected, however, in C20:5 and C22:6 concentrations. This observation was surprising because the FA profile in the PL fraction 
of PBMC typically reflects that of the circulating FA profile (Contreras et al., 2010; Watts et al., 2013). The relatively short prepartum feeding period, parturition, or dietary change post parturition may have interrupted this relationship. In the present study, greater serum concentrations of C18:3n-3 in NEFA and PL were observed in control animals. Given the relatively small proportion of $\mathrm{C} 18: 3 \mathrm{n}-3$ in the PL fraction of PBMC, observed difference may be physiologically negligible. Fatty acids in greatest concentration in the PL fraction of PBMC were similar to those in the NEFA fraction with C16:0 (22.8 g/100 g of FAME), C18:0 (19.5 g/100 $\mathrm{g}$ of FAME), and C18:1 cis (16.3 g/100 g of FAME).
Neutrophils, the primary cell type in PMNL, serve vital roles as phagocytes as well as in the production of cytokines and lipid mediators to signal and recruit nearby cells to aid in the immune response (Paape et al., 2003). Alterations to the FA profile of PMNL result in changes similar to those observed in PBMC. In this study, several FA differed in the PL fraction of PMNL (Table 5). Although no difference was detected in C18:3n-3 concentrations, C20:5 varied by treatment across time and parity $(P<0.01)$. Primiparous cows had greater concentrations of $\mathrm{C} 20: 5$ than multiparous cows, and the control group had greater quantities than the treatment group. Greater available C20:5 can alter

Table 3. Least squares means of fatty acid methyl esters $(\mathrm{g} / 100 \mathrm{~g})$ of the nonesterified fatty acid fraction of peripheral blood mononuclear cells obtained from dairy cows [14 multiparous (M) and 20 primiparous $(\mathrm{P})]$ that received either the treatment of $10 \mathrm{~kg}$ of corn/head per day prepartum and were fasted for $8 \mathrm{~h}$ on d 3 postpartum (TRT) or control of $400 \mathrm{mg}$ of monensin/head per day prepartum (CON) throughout the periparturient period

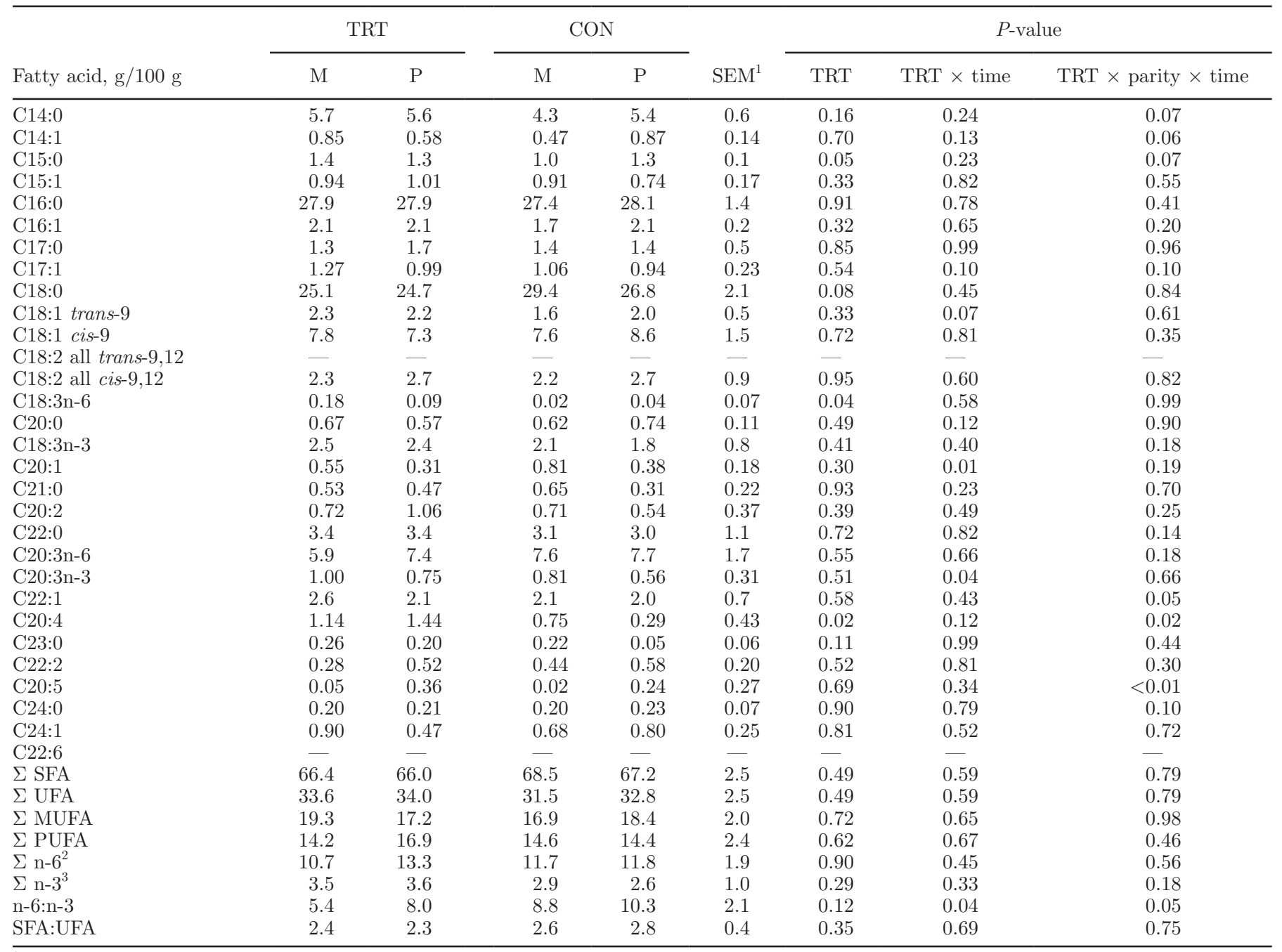

${ }^{1}$ Largest SEM reported.

${ }^{2} \mathrm{n}-6$ included C18:2 all trans-9,12, C18:2 all cis-9,12, C18:3n-6, C20:2, C20:3n-6, C20:4, and C22:2.

${ }^{3} \mathrm{n}-3$ included C18:3n-3, C20:3n-3, C20:5, and C22:6. 

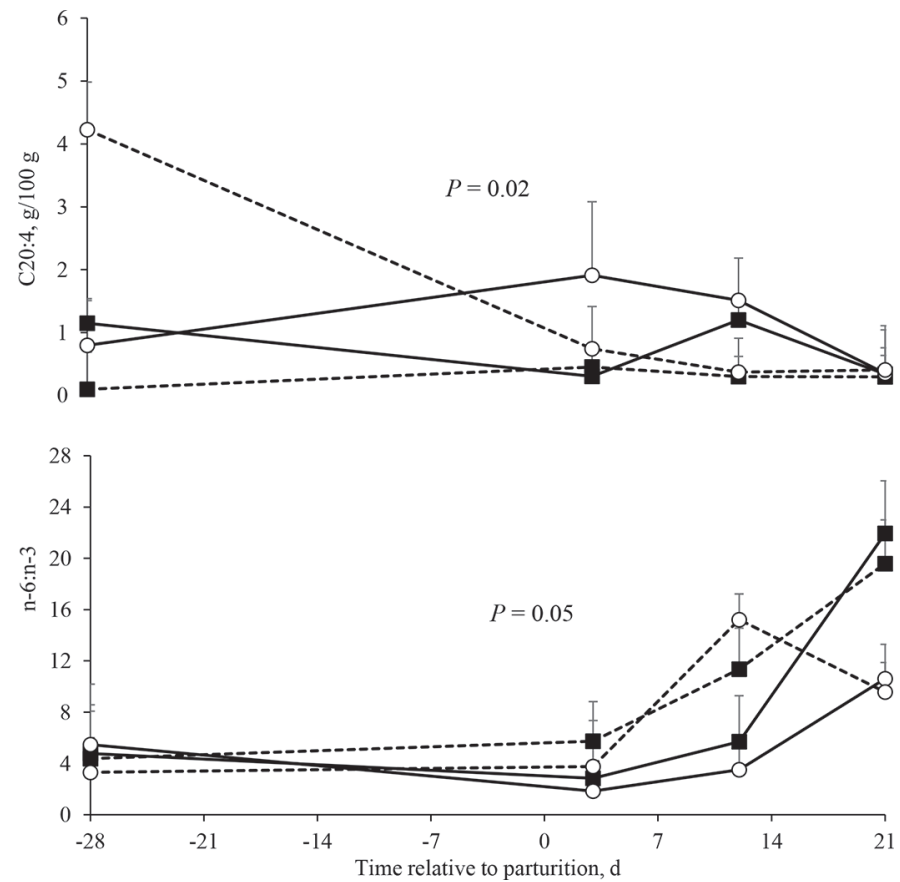

Figure 3. Least squares means $( \pm \mathrm{SE})$ of C20:4 (g/100 g) profile and n-6:n-3 ratio of the nonesterified fatty acid fraction of peripheral blood mononuclear cell samples obtained from periparturient dairy cows [14 multiparous (solid line) and 20 primiparous (dashed line)] that received either the treatment (open circle; $\bigcirc$ ) of $10 \mathrm{~kg}$ of corn/ head per day prepartum and were fasted for $8 \mathrm{~h}$ on $\mathrm{d} 3$ postpartum or control (closed square; $\mathbf{0}$ ) of $400 \mathrm{mg}$ of monensin/head per day prepartum.

eicosanoid production and result in synthesis of less potent proinflammatory mediators, decreased cytokine production, and more anti-inflammatory mediators (Calder, 2005). These mediators are beneficial in a chronic inflammatory state; however, decreased synthesis of cytokines and proinflammatory mediators can alter the immune response and lead to an immunosuppressed state. These reported concentrations of C20:5 are relatively small in the total PL fraction; therefore, the overall influence of C20:5 on PMNL function in the immune response is likely to be minimal because FA influence occurs in a dose-dependent manner (Calder, 2008). Limited information exists on the FA profile of PMNL. Kawakami et al. (2007) reported a limited FA profile from neutrophils isolated from humans with much higher quantities of C20:5. In the current study, ratio of n- 6 to n- 3 varied by treatment across time and parity as seen in several other fractions with similar response in that multiparous cows had greater concentrations than primiparous cows $(P<0.01$; Figure 4$)$.

Individual FA in milk can arise from 2 main sources: de novo synthesis and uptake from circulation. These circulating free FA can originate from either dietary absorption or mobilization of adipose stores (Bauman and Davis, 1974). During early lactation when lipid mobilization is elevated, NEFA from adipose can account for approximately $40 \%$ of milk FA (Bell, 1995). In the current experiment, detection of milk FAME for de novo synthesized FA (less than 14 carbons in length) and many long-chain FA, specifically C20:4 and C20:5, through gas chromatography was limited. The mean composition of the FAME detected in milk and sums of FA and ratios, therefore, do not fully reflect the FA profile of milk lipids. Of the FAME detected, concentration of C18:3n-3 varied by treatments across time $(P<0.01)$, with control animals having greater concentrations than treatment animals (Figure 1). Concentrations in the control group peaked shortly after parturition before declining to concentrations similar to those of the treatment group. As mentioned previously, high-forage rations, similar to the control group ration prepartum, have high concentrations of $\mathrm{C} 18: 3 \mathrm{n}-3$ within the ration $(31.6 \mathrm{~g} / 100 \mathrm{~g}$ of FAME C18:3n-3). Han et al. (2014) reported similar milk C18:3n-3 concentrations from cows fed a high-forage diet.

Ratio of total n- 6 to n-3 FA varied across treatments by parity and time interaction $(P<0.01 ;$ Figure 5$)$. Both total n- 6 and total n-3 FA appeared to be contributing factors for the overall changes in the ratio. Multiparous cows had greater ratios than primiparous cows after $\mathrm{d}+3$. Within parity, treatment animals had a greater n-6:n-3 than control animals (Table 6). Benbrook et al. (2013) reported a similar n-6:n-3 ratio in milk from cows fed conventional diets. High $\mathrm{n}-6$ intake is associated with increased inflammation through greater production of proinflammatory mediators (Calder, 2001). Supplementing diets with high concentrations of n-3, such as C20:5 and C22:6 typically found in fish oils, are reported to have anti-inflammatory effects through decreased production of proinflammatory and increased anti-inflammatory mediators (Calder, 2005). Only trace amounts of $\mathrm{C} 22: 6$ and no $\mathrm{C} 20: 5$ were detected in the milk FA profile in the current study. With the growing concern about rising n-6:n-3 in human diets and its associated potential for exacerbating cardiovascular disease, diabetes, and inflammation (Elwood et al., 2010), it is interesting to note the effect of the high-energy prepartum treatment ration and feed deprivation in increasing the n-6: n-3 ratio in early lactating cows.

The FA profile of the prepartum ration was primarily C18:3n-3 (31.6 g/100 g of FAME), C16:0 (24.8 g/100 g of FAME), C18:2 cis (20.8 g/100 g of FAME), and total $\mathrm{C} 18: 1$ cis (11.4 g/100 g of FAME). High concentrations of C18:3n-3 are typical for a high-forage diet, such as a dry cow diet (Han et al., 2014). The postpartum ration had greater concentrations of total C18:1 cis $(34.3 \mathrm{~g} / 100$ $\mathrm{g}$ of FAME) and C18:2 cis (24.8 g/100 g of FAME) and a decreased C18:3n-3 (4.7 g/100 g of FAME) concentra- 
tion. The increase in C18:2 cis and decrease in C18:3n-3 from the prepartum to postpartum ration were likely the primary contributors to the increase in total n-6:n-3 from 0.68 in the prepartum ration to 5.2 postpartum. This change is expected because the postpartum diet has decreased forage and increased corn, dry distillers' grains, barley, and calcium soaps of FA. Long-chain FA C20:4 (0.13 vs. $0.03 \mathrm{~g} / 100 \mathrm{~g}$ of FAME) and C22:6 (0.65 vs. $0.08 \mathrm{~g} / 100 \mathrm{~g}$ of FAME) concentrations were greater in the prepartum ration as well. Although these FA only constitute a small fraction of detected FAME, it is important to note their changes across rations because their pro- and anti-inflammatory effects are dose dependent (Calder, 2008).

\section{Gene Expression}

During the periparturient period, expression of all proinflammatory genes in PBMC and PMNL changed over time (Table 7). Relative to prepartum, ICAM, $I L$ $1 \beta, I L-6$, and $T N F-\alpha$ expression in PBMC and $I L-8 R$ and $S E L L$ expression in PMNL increased as lactation progressed, indicating that immune cells were likely entering a proinflammatory state as also observed in the transition cows' liver (Bionaz et al., 2007; Graugnard et al., 2013). Treatment effects were detected for $I L$ $1 \beta$ mRNA expression in PBMC. Expression of $I L-1 \beta$ was greater in the control as compared to that for the treatment (3.88 vs. $4.69 \mathrm{Ct} ; P=0.04$; Table 8). In an

Table 4. Least squares means of fatty acid methyl esters $(\mathrm{g} / 100 \mathrm{~g})$ of the phospholipids fatty acid fraction of peripheral blood mononuclear cells obtained from dairy cows [14 multiparous $(\mathrm{M})$ and 20 primiparous $(\mathrm{P})]$ that received either the treatment of $10 \mathrm{~kg}$ of corn/head per day prepartum and were fasted for $8 \mathrm{~h}$ on d 3 postpartum (TRT) or control of $400 \mathrm{mg}$ of monensin/head per day prepartum (CON) throughout the periparturient period

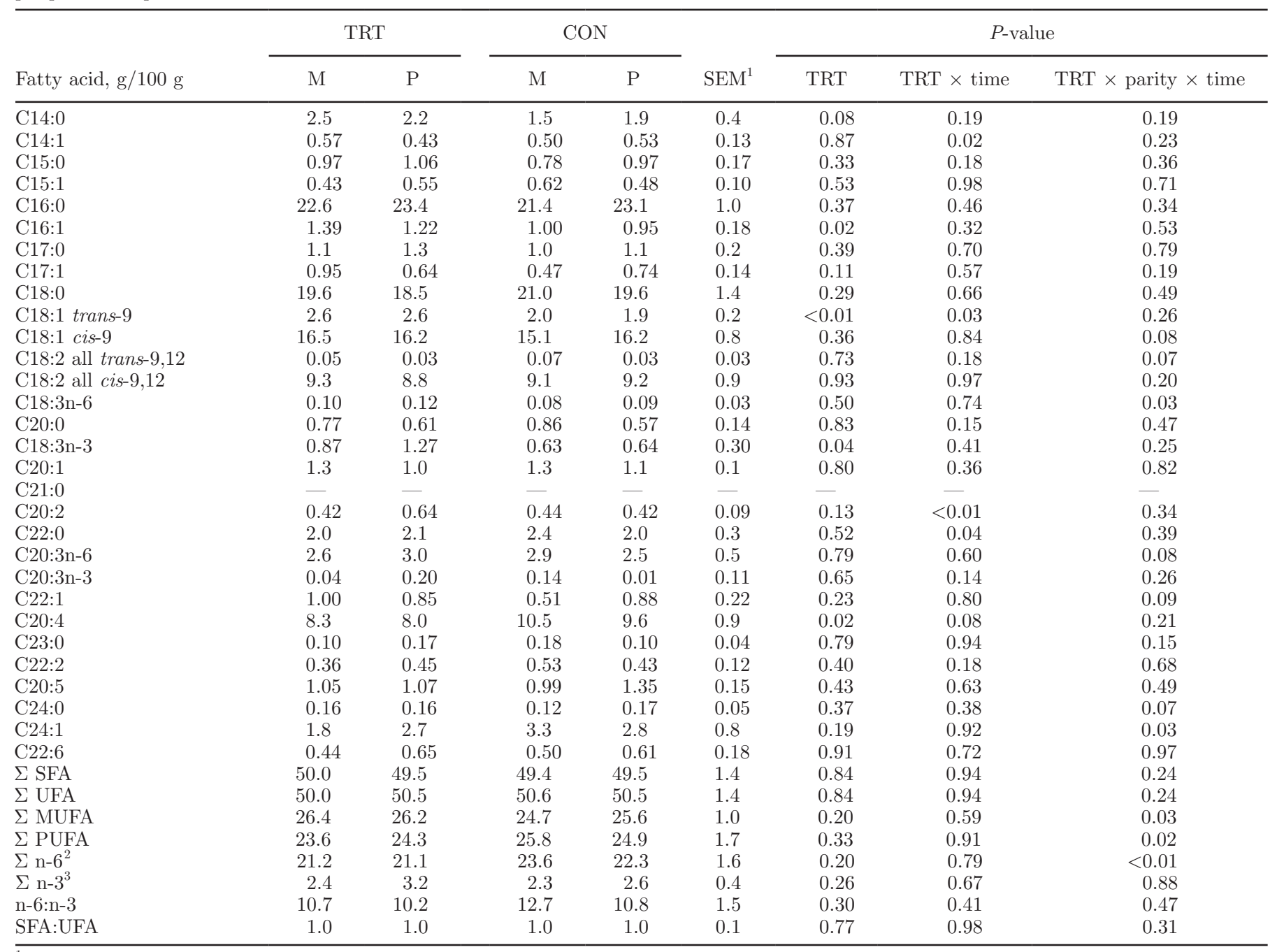

${ }^{1}$ Largest SEM reported.

${ }^{2} \mathrm{n}-6$ included C18:2 all trans-9,12, C18:2 all cis-9,12, C18:3n-6, C20:2, C20:3n-6, C20:4, and C22:2.

${ }^{3} \mathrm{n}-3$ included C18:3n-3, C20:3n-3, C20:5, and C22:6. 
immune response, activated macrophages secrete $I L$ $1 \beta$ to elicit many cellular activities such as leukocyte activation, increased ICAM expression, and synthesis and release of other proinflammatory cytokines (e.g., $T N F-\alpha$ and $I L-6$; Netea et al., 2010). Decreased expression of $I L-1 \beta$ in treatment animals suggests a potentially reduced immune response and increased risk for diseases, such as mastitis and metritis.

A similar decrease in $I L-1 \beta$ production was observed in human monocytes when diets were enriched in C18:3n-3 (Caughey et al., 1996). Although differences in C18:3n-3 between treatment groups in the PL fraction of PBMC were physiologically negligible, PBMC expression of $I L-1 \beta$ may have been lower in treatment animals because of their higher concentration of $\mathrm{C} 18: 3 \mathrm{n}-3$ present in the PL fraction of PBMC. As reviewed by Calder (2005), monocytes and macrophages exposed to various $\mathrm{n}-3$ had decreased ICAM, $I L-1 \beta, T N F-\alpha$, and $I L-6$ expression because of altered eicosanoid metabolism (Chu et al., 1999; Wallace et al., 2003; Miles et al., 2000), resulting in altered immune response to pathogens. Although in the current study no detectable treatment effects were observed for $I C A M, I L-1 \beta, I L-6$ and TNF- $\alpha$ gene expression, the relatively low concentrations of $n-3$ in the PL fraction of PBMC might not have been sufficient to elicit a downregulated expression of proinflammatory mediators tested. Alternatively, high concentrations of C20:4 in

Table 5. Least squares means of FAME (g/100 g) of the phospholipids fatty acid fraction of PMNL obtained from dairy cows [14 multiparous $(\mathrm{M})$ and 20 primiparous $(\mathrm{P})]$ that received either the treatment of $10 \mathrm{~kg}$ of corn/head per day prepartum and were fasted for $8 \mathrm{~h}$ on $\mathrm{d} 3$ postpartum (TRT) or control of $400 \mathrm{mg}$ of monensin/head per day prepartum (CON) throughout the periparturient period

\begin{tabular}{|c|c|c|c|c|c|c|c|c|}
\hline \multirow[b]{2}{*}{ Fatty acid, g/100 g } & \multicolumn{2}{|c|}{ TRT } & \multicolumn{2}{|c|}{$\mathrm{CON}$} & \multirow[b]{2}{*}{$\mathrm{SEM}^{1}$} & \multicolumn{3}{|c|}{$P$-value } \\
\hline & M & $\mathrm{P}$ & M & $\mathrm{P}$ & & TRT & TRT $\times$ time & $\mathrm{TRT} \times$ parity $\times$ time \\
\hline $\mathrm{C} 14: 0$ & 2.2 & 1.4 & 1.5 & 1.3 & 0.4 & 0.27 & 0.80 & 0.16 \\
\hline C14:1 & 0.37 & 0.31 & 0.24 & 0.27 & 0.06 & 0.09 & 0.38 & 0.40 \\
\hline C15:0 & 0.46 & 0.54 & 0.39 & 0.47 & 0.07 & 0.21 & 0.55 & 0.08 \\
\hline C15:1 & - & - & - & - & - & - & - & - \\
\hline C16:0 & 20.4 & 19.8 & 18.2 & 17.8 & 1.1 & 0.04 & 0.79 & 0.19 \\
\hline C16:1 & 0.86 & 0.53 & 0.84 & 0.71 & 0.20 & 0.59 & 0.11 & 0.29 \\
\hline C17:0 & 0.64 & 0.72 & 0.63 & 0.73 & 0.04 & 0.90 & 0.62 & 0.18 \\
\hline $\mathrm{C} 17: 1$ & 0.21 & 0.28 & 0.25 & 0.27 & 0.04 & 0.62 & 0.95 & 0.15 \\
\hline C18:0 & 19.3 & 19.8 & 21.2 & 19.5 & 1.0 & 0.32 & 0.24 & 0.28 \\
\hline C18:1 trans-9 & 2.0 & 1.8 & 1.5 & 1.6 & 0.2 & 0.09 & 0.20 & 0.10 \\
\hline $\mathrm{C} 18: 1$ cis-9 & 19.7 & 17.4 & 15.8 & 15.7 & 1.3 & 0.02 & 0.18 & 0.12 \\
\hline $\mathrm{C} 18: 2$ all trans-9,12 & - & - & - & - & - & - & - & - \\
\hline C18:2 all cis- 9,12 & 23.1 & 25.5 & 27.4 & 27.5 & 2.0 & 0.09 & 0.48 & 0.11 \\
\hline C18:3n-6 & 0.12 & 0.08 & 0.09 & 0.14 & 0.03 & 0.56 & 0.15 & - \\
\hline C20:0 & 0.32 & 0.31 & 0.33 & 0.34 & 0.04 & 0.52 & 0.34 & 0.54 \\
\hline C18:3n-3 & 1.6 & 1.1 & 1.1 & 1.7 & 0.5 & 0.89 & 0.60 & 0.46 \\
\hline C20:1 & 0.84 & 0.68 & 0.80 & 0.64 & 0.06 & 0.40 & 0.80 & 0.15 \\
\hline $\mathrm{C} 21: 0$ & 0.30 & 0.21 & 0.19 & 0.20 & 0.13 & 0.52 & 0.54 & 0.08 \\
\hline C20:2 & 0.18 & 0.28 & 0.23 & 0.26 & 0.04 & 0.68 & 0.59 & 0.55 \\
\hline $\mathrm{C} 22: 0$ & 1.4 & 1.4 & 1.9 & 1.6 & 0.2 & 0.02 & 0.01 & 0.07 \\
\hline $\mathrm{C} 20: 3 n-6$ & 0.53 & 0.52 & 0.71 & 0.58 & 0.14 & 0.29 & 0.33 & 0.23 \\
\hline C20:3n-3 & 0.47 & 0.22 & 0.31 & 0.44 & 0.14 & 0.78 & 0.31 & 0.53 \\
\hline $\mathrm{C} 22: 1$ & - & - & - & - & - & - & - & - \\
\hline C20:4 & 4.4 & 5.4 & 5.4 & 5.9 & 0.7 & 0.20 & 0.01 & 0.12 \\
\hline C23:0 & 0.01 & 0.02 & 0.01 & 0.07 & 0.01 & 0.10 & 0.03 & $<0.01$ \\
\hline $\mathrm{C} 22: 2$ & 0.12 & 0.24 & 0.19 & 0.22 & 0.07 & 0.68 & 0.64 & 0.20 \\
\hline $\mathrm{C} 20: 5$ & 0.27 & 0.74 & 0.33 & 1.16 & 0.10 & 0.01 & $<0.01$ & $<0.01$ \\
\hline C24:0 & 0.06 & 0.11 & 0.06 & 0.05 & 0.02 & 0.15 & 0.16 & 0.51 \\
\hline $\mathrm{C} 24: 1$ & 0.34 & 0.26 & 0.42 & 0.34 & 0.08 & 0.24 & 0.04 & 0.56 \\
\hline $\mathrm{C} 22: 6$ & 0.14 & 0.38 & 0.14 & 0.49 & 0.06 & 0.32 & 0.31 & - \\
\hline$\Sigma \mathrm{SFA}$ & 45.0 & 44.4 & 44.3 & 42.0 & 1.3 & 0.17 & 0.33 & 0.15 \\
\hline$\Sigma \mathrm{UFA}$ & 55.0 & 55.6 & 55.7 & 58.0 & 1.3 & 0.17 & 0.33 & 0.15 \\
\hline$\Sigma$ MUFA & 24.3 & 21.2 & 20.0 & 19.6 & 1.6 & 0.03 & 0.24 & 0.12 \\
\hline$\Sigma$ PUFA & 30.7 & 34.4 & 35.8 & 38.5 & 2.6 & 0.05 & 0.24 & 0.21 \\
\hline$\Sigma \mathrm{n}-6^{2}$ & 28.2 & 31.9 & 33.9 & 34.6 & 2.4 & 0.06 & 0.24 & 0.12 \\
\hline$\sum \mathrm{n}-3^{3}$ & 2.5 & 2.5 & 1.9 & 3.8 & 0.6 & 0.46 & 0.82 & 0.22 \\
\hline$n-6: n-3$ & 19.1 & 14.4 & 20.7 & 10.9 & 1.3 & 0.44 & 0.42 & $<0.01$ \\
\hline SFA:UFA & 0.87 & 0.82 & 0.82 & 0.74 & 0.04 & 0.10 & 0.29 & - \\
\hline
\end{tabular}

${ }^{1}$ Largest SEM reported.

${ }^{2}$ n-6 included C18:2 all trans-9,12, C18:2 all cis-9,12, C18:3n-6, C20:2, C20:3n-6, C20:4, and C22:2.

${ }^{3} \mathrm{n}-3$ included C18:3n-3, C20:3n-3, C20:5, and C22:6. 

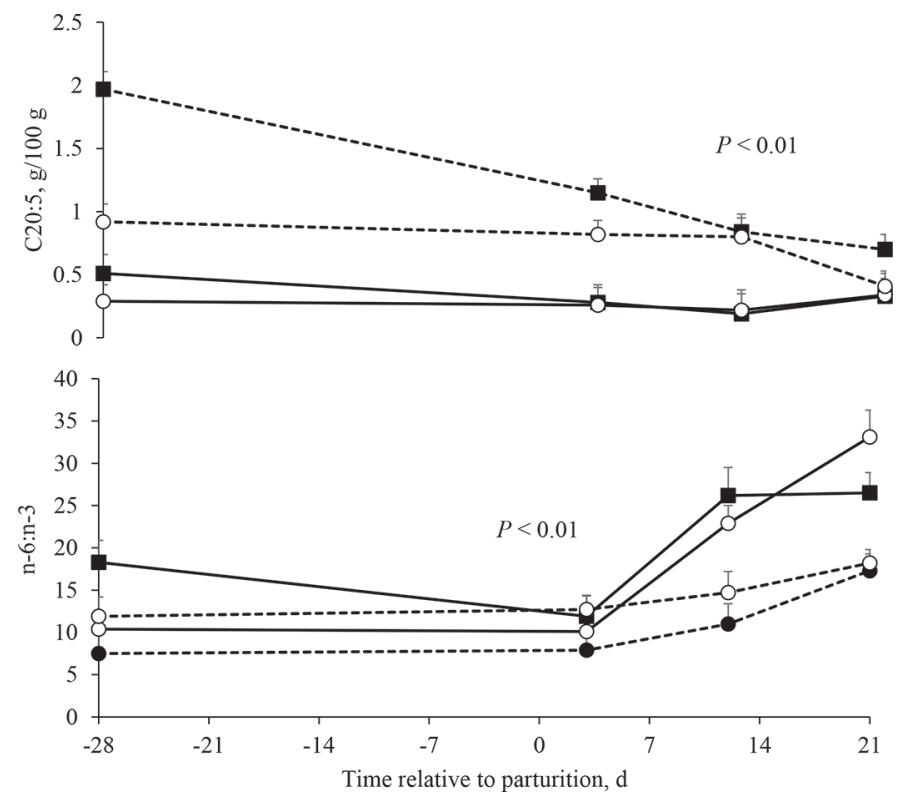

Figure 4. Least squares means $( \pm \mathrm{SE})$ of $\mathrm{C} 20: 5(\mathrm{~g} / 100 \mathrm{~g})$ and $\mathrm{n}-$ 6:n-3 profile of the phospholipids fraction of PMNL samples obtained from periparturient dairy cows [14 multiparous (solid line) and 20 primiparous (dashed line)] that received either the treatment (open circle; O) of $10 \mathrm{~kg}$ of corn/head per day prepartum and were fasted for $8 \mathrm{~h}$ on d 3 postpartum or control (closed square; $\mathbf{0}$ ) of $400 \mathrm{mg}$ of monensin/head per day prepartum.

the cellular PL fraction can be mobilized to synthesize proinflammatory eicosanoids, such as prostaglandins, cyclo-oxygenases, and leukotrienes. Greater eisocanoid production, most notably leukotriene B4, is noted to increase IL-1, IL-6, and TNF- $\alpha$ synthesis (Calder, 2005). Greater concentrations of $\mathrm{C} 20: 4$ in the PL fraction of PBMC from control cows as well as increased concentrations of PL during the postpartum period (Bionaz et al., 2007) may have influenced greater $I L-1 \beta$ gene expression. Because $I L-6$ and $T N F-\alpha$ gene expression were not affected by treatment, it remains difficult to fully elucidate the effects of the $\mathrm{n}-6$, proinflammatory FA, and confounding effects of n-3 anti-inflammatory FA.

In PMNL, no treatment effects were detected for $C A S P, I L-8 R$, and SELL mRNA expression. Lack of significant differences may relate to the relatively short life span of PMNL of approximately $9 \mathrm{~h}$ (Carlson and Kaneko, 1975) and the limited sampling in the current study. Zhou et al. (2015) also observed minimal changes in periparturient PMNL gene expression in Holstein cows treated with a high-energy prepartum diet. In comparison with the known effects of FA supplementation on inflammatory mediator production and mRNA expression of PBMC, the effects are almost unknown on PMNL. A similar pattern of altered production and mRNA expression in PMNL would also be expected, but it was not observed in the current study. Scalia et al. (2006) reported decreased viability and increased necrosis in PMNL exposed to concentrations of NEFA typically observed in periparturient dairy cows. The physiological mechanism for these observations is not well defined but likely involves altered cytokine production, based on the findings of the current study. Further research is needed to elucidate the effects of altered FA composition on PMNL mRNA expression and protein abundance of proinflammatory mediators.

\section{Production Measures}

Prepartum DMI differed between groups, with the control group consuming less feed than the treatment group (8.9 vs. $14.8 \pm 0.6 \mathrm{~kg}, P<0.01)$. This difference was also reflected in prepartum DMI as a percentage of BW (1.60 vs. $2.55 \pm 0.04 \%$ for control and treatment, respectively, $P<0.01$ ). Although cows in the control group had unexpectedly low prepartum feed intake, no increase occurred in observed clinical symptoms of metabolic disorders and disease as is typically observed. Grummer et al. (2004) found similar averages for DMI as primiparous and multiparous animals consumed 1.3 and $1.4 \%$, respectively. Prepartum DMI also differed by treatment across time $(P=0.01)$. Postpartum intake did not vary between treatment groups. Although cows fed restricted diets prepartum have been reported to have greater DMI postpartum (Douglas et al., 2006; Holcomb et al., 2001), this outcome was not observed in the current experiment, possibly because of the limited duration of the postpartum sampling period of only 3 wk as compared with other studies that continued for at least 6 wk.

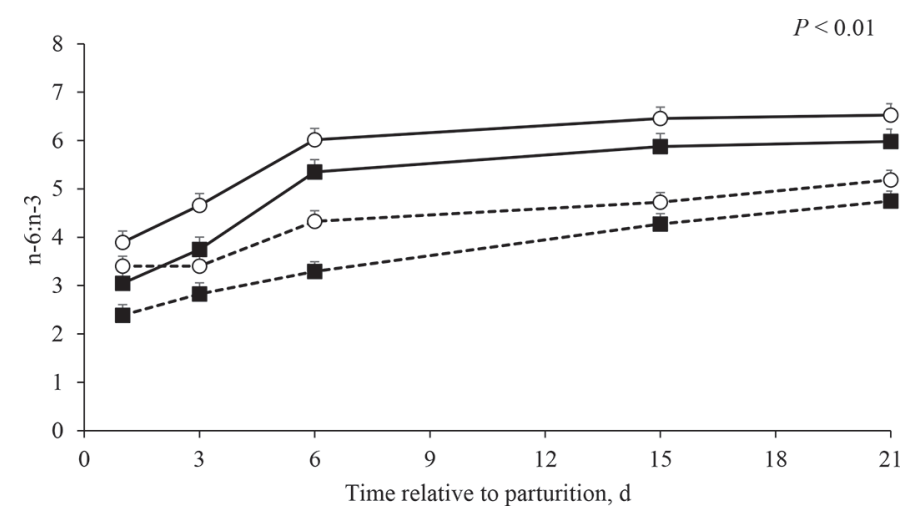

Figure 5. Least squares means $( \pm \mathrm{SE})$ of n-6:n-3 ratio in milk samples obtained from periparturient dairy cows [14 multiparous (solid line) and 20 primiparous (dashed line)] that received either the treatment (open circle; $\bigcirc$ ) of $10 \mathrm{~kg}$ of corn/head per day prepartum and were fasted for $8 \mathrm{~h}$ on d 3 postpartum or control (closed square; $\square$ ) of $400 \mathrm{mg}$ of monensin/head per day prepartum. 
Table 6. Least squares means of FAME (g/100 g) of milk obtained from dairy cows [14 multiparous (M) and 20 primiparous (P)] that received either the treatment of $10 \mathrm{~kg}$ of corn/head per day prepartum and were fasted for $8 \mathrm{~h}$ on $\mathrm{d} 3$ postpartum (TRT) or control of $400 \mathrm{mg}$ of monensin/head per day prepartum $(\mathrm{CON})$ throughout the periparturient period

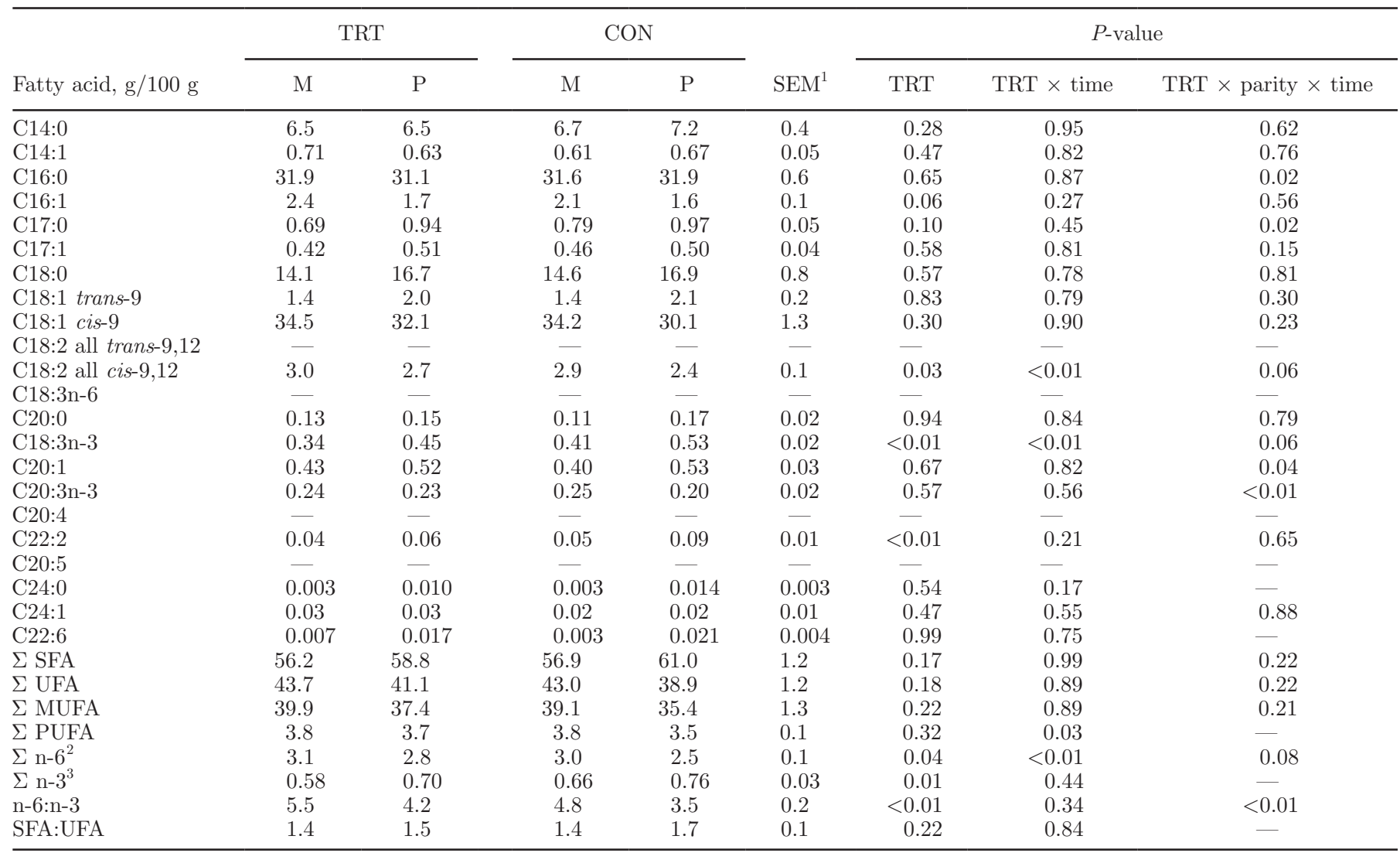

${ }^{1}$ Largest SEM reported.

${ }^{2} \mathrm{n}-6$ included C18:2 all trans-9,12, C18:2 all cis-9,12, C18:3n-6, C20:2, C20:3n-6, C20:4, and C22:2.

${ }^{3} \mathrm{n}-3$ included C18:3n-3, C20:3n-3, C20:5, and C22:6.

Table 7. Fold change $\left(2^{-\Delta \Delta \mathrm{Ct}}\right)$ relative to $\mathrm{d}-28$ of intracellular adhesion molecule $(I C A M), I L-1 \beta, I L-6$, and tumor necrosis factor $(T N F)$ - $\alpha$ of peripheral blood mononuclear cells and caspase-1 (CASP), IL-8 receptor $(I L$ $8 R)$, and L-selectin $(S E L L)$ of $\mathrm{PMNL}^{1}$

\begin{tabular}{|c|c|c|c|c|c|c|}
\hline \multirow[b]{2}{*}{ Gene } & \multicolumn{4}{|c|}{ Day } & \multirow[b]{2}{*}{$\mathrm{SEM}^{2}$} & \multirow[b]{2}{*}{$P$-value, time } \\
\hline & -28 & 3 & 12 & 21 & & \\
\hline \multicolumn{7}{|c|}{ Mononuclear cells } \\
\hline$I C A M$ & 1.00 & 1.89 & 1.71 & 3.25 & 0.252 & $<0.001$ \\
\hline$I L-1 \beta$ & 1.00 & 4.30 & 6.69 & 32.74 & 0.356 & $<0.001$ \\
\hline$I L-6$ & 1.00 & 3.47 & 3.40 & 9.72 & 0.397 & $<0.001$ \\
\hline$T N F-\alpha$ & 1.00 & 1.21 & 1.12 & 4.18 & 0.264 & $<0.001$ \\
\hline \multicolumn{7}{|l|}{ PMNL } \\
\hline$C A S P$ & 1.00 & 0.79 & 0.62 & 0.47 & 0.189 & $<0.001$ \\
\hline$I L-8 R$ & 1.00 & 0.60 & 1.35 & 2.34 & 0.239 & $<0.001$ \\
\hline$S E L L$ & 1.00 & 0.73 & 0.79 & 2.06 & 0.14 & $<0.001$ \\
\hline
\end{tabular}

${ }^{1}$ Mononuclear cells and PMNL were obtained from dairy cows [14 multiparous (M) and 20 primiparous $\left.(\mathrm{P})\right]$ that received either the treatment of $10 \mathrm{~kg}$ of corn/head per day prepartum and were fasted for $8 \mathrm{~h}$ on $\mathrm{d} 3$ postpartum (TRT) or control of $400 \mathrm{mg}$ of monensin/head per day prepartum (CON) throughout the transition period.

${ }^{2}$ Largest SEM reported. 
Table 8. Least squares means of delta cycle threshold $(\mathrm{Ct})$ values of intracellular adhesion molecule (ICAM), $I L-1 \beta, I L-6$, and tumor necrosis factor $(T N F)$ - $\alpha$ of peripheral blood mononuclear cells and caspase-1 $(C A S P)$, IL-8 receptor $(I L-8 R)$, and L-selectin $(S E L L)$ of $\mathrm{PMNL}^{1}$

\begin{tabular}{|c|c|c|c|c|c|c|}
\hline \multirow[b]{2}{*}{ Gene } & \multicolumn{2}{|c|}{ TRT } & \multicolumn{2}{|c|}{$\mathrm{CON}$} & \multirow[b]{2}{*}{$\mathrm{SEM}^{2}$} & \multirow[b]{2}{*}{$P$-value, TRT } \\
\hline & M & $\mathrm{P}$ & M & $\mathrm{P}$ & & \\
\hline \multicolumn{7}{|c|}{ Mononuclear cells } \\
\hline$I C A M$ & 8.4 & 7.3 & 8.7 & 7.2 & 0.4 & 0.91 \\
\hline$I L-1 \beta$ & 5.7 & 3.7 & 4.7 & 3.1 & 0.4 & 0.04 \\
\hline$I L-6$ & 13.6 & 11.8 & 13.3 & 11.5 & 0.6 & 0.55 \\
\hline$T N F-\alpha$ & 4.8 & 3.6 & 4.3 & 3.5 & 0.4 & 0.39 \\
\hline \multicolumn{7}{|l|}{ PMNL } \\
\hline$C A S P$ & 6.4 & 6.3 & 6.4 & 6.4 & 0.2 & 0.72 \\
\hline$I L-8 R$ & -0.23 & -0.64 & 0.43 & -0.48 & 0.42 & 0.28 \\
\hline SELL & 0.76 & 0.54 & 0.91 & 0.56 & 0.18 & 0.58 \\
\hline
\end{tabular}

${ }^{1}$ Mononuclear cells and PMNL were obtained from dairy cows [14 multiparous (M) and 20 primiparous (P)] that received either the treatment of $10 \mathrm{~kg}$ of corn/head per day prepartum and were fasted for $8 \mathrm{~h}$ on $\mathrm{d} 3$ postpartum (TRT) or control of $400 \mathrm{mg}$ of monensin/head per day prepartum (CON) throughout the transition period.

${ }^{1}$ Largest SEM reported.

Because of the high concentration of additional corn in the treatment prepartum diet, animals may have experienced subclinical ruminal acidosis (Plaizier et al., 2008). Rumen $\mathrm{pH}$ was not sampled to confirm or exclude the pathology; however, several mechanisms were used to minimize possible effects. Forage in the TMR was selectively longer, preventing some rapid carbohydrate fermentation. Feed was delivered twice daily within 1-h scheduled time frames and pushed up to the bunk at least an additional 2 times a day to encourage multiple smaller meals. The TMR had adequate moisture content to help concentrates and long-fiber forage stick together and prevent sorting. All pens had adequate bunk space for the housed animals to prevent meal competition and overeating.

Prepartal treatments did not alter the BW of treatment groups during the periparturient period. As expected, BW increased slightly prepartum, drastically decreased following parturition, and continued to decrease across the postpartum sampling period. Decreased BW at parturition is related to increased mobilization of subcutaneous lipid stores to compensate for negative energy balance caused by insufficient energy intake and increasing milk production (Drackley, 1999). As previously mentioned, lipid mobilization likely influenced circulating C16:0, C18:0, and C18:1 concentrations primarily because the majority of the FA profile of subcutaneous triglycerides consist of these FA (Douglas et al., 2007). Desaturation and elongation via liver enzymes can convert these circulating FA into inflammatory agonists, such as C20:4 and C18:3n-3, which can potentially influence the immune cell eicosanoid synthesis (Calder, 2005).

Milk composition varied slightly between treatment groups. Protein, as a percentage of volume over time, was greater for treatment cows $(P<0.01)$. Total milk fat yield varied by treatment $\times$ parity $\times$ time interaction $(P<0.01)$. Holcomb et al. (2001) reported similar results with cows fed a restricted prepartum diet producing significantly less milk fat, similar to multiparous control animals observed in the current study. Milk yield did not vary between treatments; however, a treatment effect across time and parity was detected for energycorrected milk $(P=0.04$; Figure 6$)$. Energy-corrected milk yield mirrored that of milk fat yield. This finding is not surprising, given the importance of milk fat yield in calculating energy corrected milk (Dairy Records Management Systems, 2013). Janovick and Drackley (2010) speculated that the increased lipid mobilization observed in cows fed an energy-dense prepartum diet is a potential mechanism for increased milk fat percentage and therefore increased energy-corrected milk. Significant differences are mostly influenced through effects of parity and time. Primiparous animals produce less quantities of milk than multiparous cows (Janovick and Drackley, 2010), in addition to milk production increasing during early lactation (Miller et al., 2006).

\section{CONCLUSIONS}

Parturition and initiation of lactation challenge all dairy cows because nutrient supply cannot keep up with nutrient demand, therefore requiring cows to mobilize protein and lipid stores. High circulating NEFA concentrations aid in fulfilling energy requirements in high-producing dairy cows when supply is limited from inadequate DMI. Cows with greater subcutaneous adipose stores usually mobilize more adipose tissue and have greater concentrations of NEFA as compared with cows with lower adipose stores. These NEFA alter the 

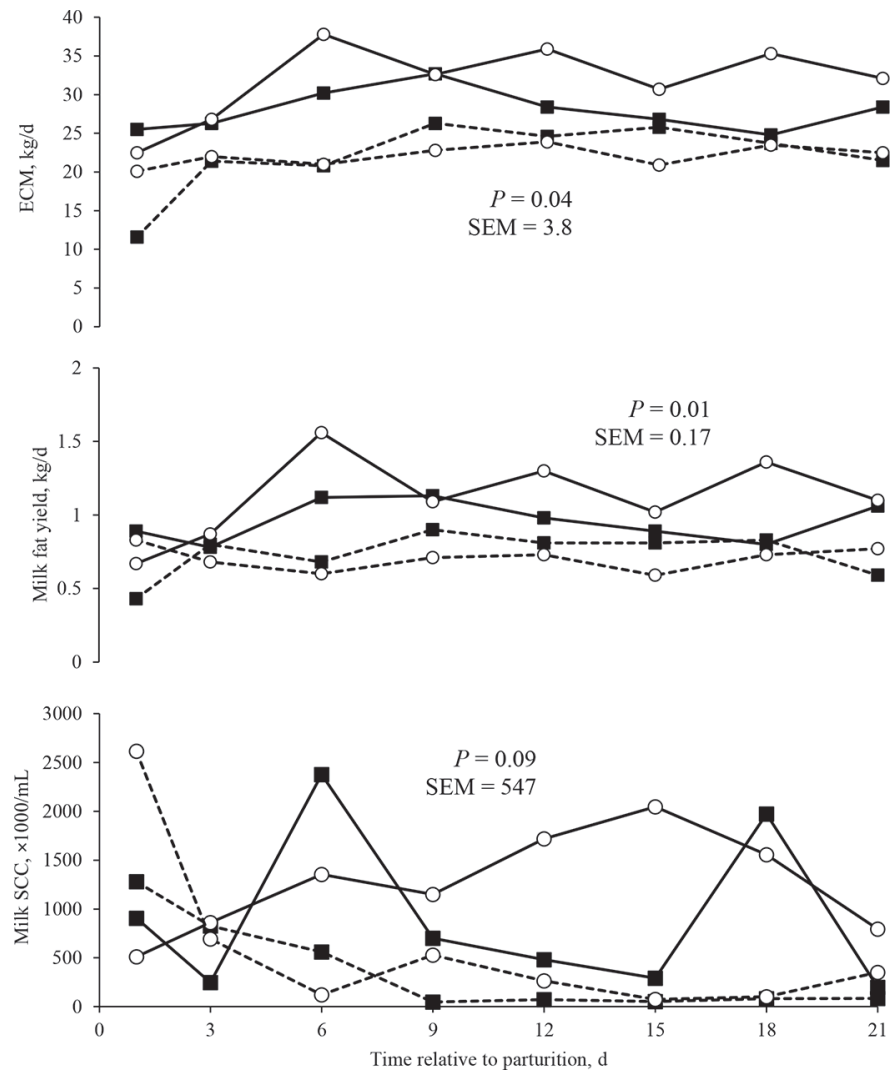

Figure 6. Least squares means of ECM yield $(\mathrm{kg} / \mathrm{d})$, milk fat yield $(\mathrm{kg} / \mathrm{d})$, and SCC of milk $(\times 1,000 / \mathrm{mL})$ samples obtained from periparturient dairy cows [14 multiparous (solid line) and 20 primiparous (dashed line)] that received either the treatment (open circle; $\bigcirc)$ of $10 \mathrm{~kg}$ of corn/head per day prepartum and were fasted for $8 \mathrm{~h}$ on $\mathrm{d} 3$ postpartum or control (closed square; ) of $400 \mathrm{mg}$ of monensin/head per day prepartum.

physiology of the cow and are possibly a contributing factor to the higher incidence of metabolic disorders and infectious diseases often observed in cows with increased fat stores. In the present study, a high-energy prepartum diet and postpartum feed deprivation were used in an attempt to increase subcutaneous fat stores and lipid mobilization around parturition. This approach led to an altered physiological state compared to a typical prepartum diet supplemented with monensin to minimize lipid mobilization. Although relatively low prepartum DMI was observed in control animals, no subsequent increase occurred in metabolic disorders and associated diseases during the postpartum period. Several FA concentrations in milk and NEFA and PL fractions in serum, PBMC, and PMNL varied because of the high-energy prepartum treatment diet interacting with time and parity. Many important n-3 and n-6 FA, such as C20:5 (n-3) and C20:4 (n-6), which are known to alter eicosanoid and cytokine production in immune cells, varied by treatment and therefore, presumably altered PBMC and PMNL response. Gene expression of several proinflammatory mediators that are indicative of cell function did not vary by treatment, except for decreased $I L-1 \beta$ expression in PBMC in treatment animals. Given the relatively brief life span of these immune cells, especially neutrophils in the PMNL fraction, it is possible that effects were not observed because of high cellular turnover in addition to the short sampling period. Further research is needed to fully understand the effects of changes to FA profile from excessive lipid mobilization, as measured by circulating metabolites and dietary manipulation, to influence subcutaneous fat stores through analysis of other inflammatory mediators and greater sampling of immune cells to observe physiological changes.

\section{ACKNOWLEDGMENTS}

The authors thank A. Hendrickson, J. Murray, J. Williams, J. Watts, S. M. Stansfield, and S. L. Shields (all from the University of Idaho, Moscow) for technical assistance with this project as well as J. Peak and the staff at the University of Idaho Dairy Research and Teaching Center for their assistance with animal handling. This project was supported, in part, by Virtus Nutrition (Corcoran, CA) and Elanco Animal Health (Greenfield, IN), and the Idaho Agricultural Experiment Station (University of Idaho, Moscow).

\section{REFERENCES}

Bauman, D. E., and C. L. Davis. 1974. Biosynthesis of milk fat. Pages 31-75 in Lactation: A Comprehensive Treatise. Vol. 2. Biosynthesis and Secretion of Milk/Diseases. B. L. Larson and V. R. Smith, ed. Academic Press, New York, NY.

Bell, A. W. 1995. Regulation of organic nutrient metabolism during transition from late pregnancy to early lactation. J. Anim. Sci. $73: 2804-2819$.

Benbrook, C. M., G. Butler, M. A. Latif, C. Leifert, and D. R. Davis. 2013. Organic production enhances milk nutritional quality by shifting fatty acid composition: A United States-wide, 18-month study. PLoS One 8:e82429.

Bionaz, M., E. Trevisi, L. Calamari, F. Librandi, A. Ferrari, and G. Bertoni. 2007. Plasma paraoxonase, health, inflammatory conditions, and liver function in transition dairy cows. J. Dairy Sci. 90:1740-1750.

Calder, P. C. 2001. Polyunsaturated fatty acids, inflammation, and immunity. Lipids 36:1007-1024.

Calder, P. C. 2005. Polyunsaturated fatty acids and inflammation. Biochem. Soc. Trans. 33:423-427.

Calder, P. C. 2008. The relationship between the fatty acid composition of immune cells and their function. Prostaglandins Leukot. Essent. Fatty Acids 79(3-5):101-108.

Carlson, G. P., and J. J. Kaneko. 1975. Intravascular granulocyte kinetics in developing calves. Am. J. Vet. Res. 36:421-425.

Caughey, G. E., E. Mantzioris, R. A. Gibson, L. G. Cleland, and M. J. James. 1996. The effect on human tumor necrosis factor alpha and interleukin 1 beta production of diets enriched in n-3 fatty acids from vegetable oil or fish oil. Am. J. Clin. Nutr. 63:116-122.

Christie, W. W. 1981. The composition, structure and function of lipids in the tissues of ruminant animals. Pages $95-191$ in Lipid 
Metabolism in Ruminants. W. W. Christie, ed. Pergamon Press Ltd., Oxford, UK.

Chu, A. J., M. A. Walton, J. K. Prasad, and A. Seto. 1999. Blockade by polyunsaturated n-3 fatty acids of endotoxin-induced monocytic tissue factor activation is mediated by the depressed receptor expression in THP-1 cells. J. Surg. Res. 87:217-224.

Clark, R. M., K. E. Hundrieser, R. G. Jensen, P. B. Brown, A. M. Ferris, and M. Fey. 1982. Changes in the lipids of human milk from 2 to 16 weeks postpartum. J. Pediatr. Gastroenterol. Nutr. $1: 311-315$.

Contreras, G. A., N. J. O'Boyle, T. H. Herdt, and L. M. Sordillo. 2010 Lipomobilization in periparturient dairy cows influences the composition of plasma nonesterified fatty acids and leukocyte phospholipid fatty acids. J. Dairy Sci. 93:2508-2516.

Douglas, G. N., T. R. Overton, H. G. Bateman II, H. M. Dann, and J. K. Drackley. 2006. Prepartal plane of nutrition, regardless of dietary energy source, affects periparturient metabolism and dry matter intake in Holstein cows. J. Dairy Sci. 89:2141-2157.

Douglas, G. N., J. Rehage, A. D. Reaulieu, A. O. Bahaa, and J. K. Drackley. 2007. Prepartum nutrition alters fatty acid composition in plasma, adipose tissue, and liver lipids of periparturient dairy cows. J. Dairy Sci. 90:2941-2959.

Drackley, J. K. 1999. Biology of dairy cows during the transition period: The final frontier? J. Dairy Sci. 82:2259-2273.

Elwood, P. C., J. E. Pickering, D. I. Givens, and J. E. Gallacher. 2010. The consumption of milk and dairy foods and the incidence of vascular disease and diabetes: an overview of the evidence. Lipids 45:925-939.

Goff, J. P. 2006. Major advances in our understanding of nutritional influences on bovine health. J. Dairy Sci. 89:1292-1301.

Graugnard, D. E., K. M. Moyes, E. Trevisi, M. J. Khan, D. Keisler, J K. Drackley, G. Bertoni, and J. J. Loor. 2013. Liver lipid content and inflammometabolic indices in peripartal dairy cows are altered in response to prepartal energy intake and postpartal intramammary inflammatory challenge. J. Dairy Sci. 96:918-935.

Grummer, R. R., D. G. Mashek, and A. Hayirli. 2004. Dry matter intake and energy balance in the transition period. Vet. Clin. North Am. Food Anim. Pract 20:447-470.

Han, R., N. Zheng, Y. Zhang, X. Zhao, D. Bu, P. An, X. Xu, S. Liu, and J. Wang. 2014. Milk fatty acid profiles in Holstein dairy cows fed diets based on corn stover or mixed forage. Arch. Anim. Nutr. 68:63-71

Holcomb, C. S., H. H. Van Horn, H. H. Head, M. B. Hall, and C. J. Wilcox. 2001. Effects of prepartum dry matter intake and forage percentage on postpartum performance of lactating dairy cows. J. Dairy Sci. 84:2051-2058.

Imhasly, S., C. Bieli, H. Naegeli, L. Nystrom, M. Ruetten, and C. Gerspach. 2015. Blood plasma lipidome profile of dairy cows during the transition period. BMC Vet. Res. 11:252.

Janovick, N. A., and J. K. Drackley. 2010. Prepartum dietary management of energy intake affects postpartum intake and lactation performance by primiparous and multiparous Holstein cows. J. Dairy Sci. 93:3086-3102.

Kaluzny, M. A., L. A. Duncan, M. V. Merritt, and D. E. Epps. 1985. Rapid separation of lipid classes in high yield and purity using bonded phase columns. J. Lipid Res. 26:135-140.

Kawakami, Y., H. Okada, Y. Murakami, T. Kawakami, Y. Ueda, D. Kunii, Y. Sakamoto, Y. Shiratori, and M. Okita. 2007. Dietary intake, neutrophil fatty acid profile, serum antioxidant vitamins and oxygen radical absorbance capacity in patients with ulcerative colitis. J. Nutr. Sci. Vitaminol. (Tokyo) 53:153-159.
Kramer, J. K. G., V. Fellner, M. E. R. Dugan, F. D. Sauer, M. M. Mossoba, and M. P. Yurawecz. 1997. Evaluating acid and base catalysts in the methylation of milk and rumen fatty acids with special emphasis on conjugated dienes and total trans fatty acids. Lipids 32:1219-1228.

Lacetera, N., D. Scalia, O. Franci, U. Bernabucci, B. Ronchi, and A. Nardone. 2004. Effects of nonesterified fatty acids on lymphocyte function in dairy heifers. J. Dairy Sci. 87:1012-1014.

Miles, E. A., F. A. Wallace, and P. C. Calder. 2000. Dietary fish oil reduces intercellular adhesion molecule 1 and scavenger receptor expression on murine macrophages. Atherosclerosis 152:43-50.

Miller, N., L. Delbecchi, D. Petitclerc, G. F. Wagner, B. G. Talbot, and P. Lacasse. 2006. Effect of stage of lactation and parity on mammary gland cell renewal. J. Dairy Sci. 89:4669-4677.

Netea, M. G., A. Simon, F. van de Veerdonk, B. J. Kullberg, J. W.

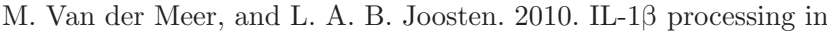
host defense: Beyond inflammasomes. PLoS Pathog. 6:e1000661.

Paape, M. J., D. B. Bannerman, X. Zhao, and J. W. Lee. 2003. The bovine neutrophil: Structure and function in blood and milk. Vet. Res. 34:597-627.

Plaizier, J. C., D. O. Krause, G. N. Gozho, and B. W. McBride. 2008. Subacute ruminal acidosis in dairy cows: The physiological causes, incidence and consequences. Vet. J. 176:21-31.

Quehenberger, O., A. M. Armando, A. H. Brown, S. B. Milne, D. S. Myers, A. H. Merrill, S. Bandyopadhyay, K. N. Jones, S. Kelly, R. L. Shaner, C. M. Sullards, E. Wang, R. C. Murphy, R. M. Barkley, T. J. Leiker, C. R. Raetz, Z. Guan, G. M. Laird, D. A. Six, D. W. Russell, J. G. McDonald, S. Subramaniam, E. Fahy, and E. A. Dennis. 2010. Lipidomics reveals a remarkable diversity of lipids in human plasma. J. Lipid Res. 51:3299-3305.

Rukkwamsuk, T., T. A. M. Kruip, and T. Wensing. 1999. Relationship between overfeeding and overconditioning in the dry period and the problems of high producing dairy cows during the postparturient period. Vet. Q. 21:71-77.

Scalia, D., N. Lacetera, U. Bernabucci, K. Demeyere, L. Duchateau, and C. Burvenich. 2006. In vitro effects of nonesterified fatty acids on bovine neutrophils oxidative burst and viability. J. Dairy Sci. $89: 147-154$

Scholte, C. M., P. Rezamand, S. L. Shields, and K. C. Ramsey. 2014. Effects of subcutaneous fat stores on serum phospholipids and nonesterified fatty acid lipid fractions in periparturient dairy cows. J. Agric. Sci. Technol. B 4:352-359.

Wallace, F. A., E. A. Mile, and P. C. Calder. 2003. Comparison of the effects of linseed oil and different doses of fish oil on mononuclear cell function in healthy human subjects. Br. J. Nutr. 89:679-689.

Watts, J. S., P. Rezamand, D. L. Sevier, W. Price, and M. A. McGuire. 2013. Short-term effects of dietary trans fatty acids compared with saturated fatty acids on selected measures of inflammation, fatty acid profiles, and production in early lactating Holstein dairy cows. J. Dairy Sci. 96:6932-6943.

Wildman, E. E., G. M. Jones, P. E. Wagner, and R. L. Boman. 1982. A dairy cow body condition scoring system and its relationship to selected production characteristics. J. Dairy Sci. 65:495-501.

Zhou, Z., D. P. Bu, M. Vallati Riboni, M. J. Khan, D. E. Graugnard, J. Luo, F. C. Cardoso, and J. J. Loor. 2015. Prepartal dietary energy level affects peripartal bovine blood neutrophil metabolic, antioxidant, and inflammatory gene expression. J. Dairy Sci. 98:5492-5505. 